A N N A L E S

UNIVERSITATIS MARIAE CURIE-SKŁODOWSKA

LUBLIN - POLONIA

VOL. LXVI, 1

SECTIO G

2019

Uniwersytet Marii Curie-Skłodowskiej w Lublinie

\author{
WOJCIECH WITKOWSKI \\ wojwit50@wp.pl \\ ORCID: 0000-0002-8188-8616
}

\title{
Z Sankt Petersburga dla czytelnika zachodnioeuropejskiego - Aleksander This o prawie Rzeczypospolitej szlacheckiej
}

From Saint Petersburg for Western European Reader - Aleksander This on the Law of the Polish-Lithuanian Commonwealth

I.

Osobie i dokonaniom naukowym Aleksandra Thisa (1803-1846) poświęciłem w $2001 \mathrm{r}$. odrębną monografię ${ }^{1}$. Był on jednym z wybitniejszych prawników Królestwa Polskiego, łączącym twórczość naukową z praktycznym działaniem w organach wymiaru sprawiedliwości. Publikował głównie w zakresie współczesnego mu prawa sądowego, cywilnego i karnego oraz publicznego. W jego dorobku znajduje się wiele prac (napisanych w latach 1831-1841) na temat teorii kodyfikacji i ustawodawstwa rosyjskiego, a także publikacje z zakresu doktryn ustrojowo-prawnych. Trwałym osiągnięciem Thisa w polskiej nauce prawa było wprowadzenie do obiegu naukowego pojęcia jurisprudentia forensis, rozumianego jako analizy orzecznictwa sądowego, oraz reguł interpretowania prawa weryfikujących w komentarzach wartość kodeksowych norm prawnych ${ }^{2}$. Pozostawał w tych kwestiach blisko filozofii Johna Austina o użyteczności prawa i bliskiej relacji między prawem sędziowskim a kodeksowym. Na gruncie polskim należał do zdecydowanych obrońców cywilnego kodeksu Napoleona, a jego publikacje znamionowało podejście formalno-dogmatyczne czy też „analityczne”, idące

1 W. Witkowski, Aleksander This i Jan Kanty Wołowski - wybitni prawnicy Królestwa Polskiego, Lublin 2001, s. 271.

2 Szerzej: ibidem, s. 197 i n. 
w kierunku późniejszego pozytywizmu prawniczego. Nie była to jednak dogmatyka ograniczona tylko do analiz orzeczeń sądowych bądź samych konstrukcji kodeksowych, ale została oparta o rzetelną wiedzę naukową, konfrontowanie użyteczności tekstu ustawowego ze stosowaniem wymiaru sprawiedliwości, a ponadto osadzona w realiach życia społecznego. Odrzucał This, zwłaszcza w pierwszej fazie twórczości w latach 1828-1830, zasadnicze tezy szkoły historycznej, mimo że nie był mu obcy, tak jak Romualdowi Hubemu, jej nurt krytyczny, wychodzący z filozofii niemieckiej od Georga W.F. Hegla i jego ucznia Eduarda Gansa.

Jeśli więc decyduję się na przedstawienie dokonanej przez Thisa oceny dawnego prawa polskiego, czynię to $\mathrm{z}$ dwóch powodów. Po pierwsze, w jego pisarstwie tekst ten ma charakter wyjątkowy, ponieważ nie uprawiał on badań historyczno-prawnych i ten wyjątek, jak się wydaje, zasługuje na uwagę. Tym bardziej, że uczynił to w sposób całościowy, choć z konieczności ogólny i przeglądowy³. Jego ujęcie bowiem - $\mathrm{i}$ to jest powód drugi - łączyło rozważania naukowe $\mathrm{z}$ celem wskazania odbiorcy francuskiemu (czy zachodnioeuropejskiemu) cech prawa nieistniejącego już państwa polskiego. W jakich okolicznościach zatem artykuł ten powstał i jakie były zamierzenia autora? Otóż This, po wybuchu powstania listopadowego, już w 1830 r. znalazł się w Petersburgu, w którym przebywał do 1841 r. Pozostawał tam w kręgu Polonii Petersburskiej, blisko związał się z domem Franciszka Malewskiego i jego żony Heleny z Szymanowskich ${ }^{4}$. Badawczo zajął się problematyką nowo tworzonego ustawodawstwa rosyjskiego, zwłaszcza powstałym w 1833 r. Swodem Zakonow. Jego zamiarem stało się przedstawienie w naukowym opracowaniu ustawodawstwa rosyjskiego w czasopiśmiennictwie prawniczym Zachodniej Europy. W połowie lat 30. przebywał przez dłuższy czas w Paryżu, gdzie nawiązał dobre kontakty ze środowiskiem prawniczym oraz redakcjami dwóch czasopism, tj. „Revue étrangére et française de législation de l'économie politique” (od 1844 r. - „Revue de droit français et étranger”), założonym przez paryskiego adwokata Jana Jakuba Foelixa, oraz „Revue de législation et de jurisprudence", wydawanym przez Ludwika Wołowskiego. W sumie w omawianym okresie This zamieścił $\mathrm{w}$ obydwu periodykach kilkanaście publikacji o prawach Rosji, a oprócz tego w głośnej serii kodeksów świata prowadzonej przez Victora Fouchera wydał we własnym tłumaczeniu Code civil de l'empire de Russie (Rennes, Paris 1841, ss. 564). Działalność Thisa przyniosła mu na gruncie francuskim opinię niekwestionowanego autorytetu i znawcy prawa Rosji. Publikacje paryskie pozostawały anonimowe głównie ze względu na polską opinię

3 Wątków historyczno-prawnych dotyczył tylko napisany w 1829 r. komentarz do wyroku Sądu Najwyższej Instancji Królestwa Polskiego w zakresie prawa spadkowego, w którym This ze znawstwem sięgnął do dawnych praw polskich (por. ibidem, s. 74-78). Dodać należy, iż przedstawionym w tym miejscu rozważaniom Thisa poświęciłem w swej książce niewielką wzmiankę, koncentrując się na innych fragmentach jego bogatej twórczości. Ibidem, s. 158.

4 Był świadkiem na ich ślubie 23 stycznia / 4 lutego 1832 r. Por. ibidem, s. 134-135. 
publiczną, szczególnie z racji aktywnego udziału w zebraniach w salonie Hanny i Franciszka Malewskich, gdzie spotykali się ludzie z różnych sfer społecznych, także z kręgu filomacko-filareckiego. Z drugiej strony aktywność naukowa Thisa i charakter jego prac nie pozostawały bez wiedzy i aprobaty czynników rosyjskich $^{5}$. Artykuł mieszczący w sobie treści o dawnym prawie polskim napisał This w 1838 r. i opublikował w piątym tomie „Revue Étrangére” pt. Notice sur la coordination des lois provinciales de l'Empire de Russie $e^{6}$. Tytuł ten słusznie sugerował podjęcie przez autora problematyki kodyfikacji praw prowincjonalnych (zakony miestnyje) na obszarze Cesarstwa Rosyjskiego. Była to kwestia wówczas aktualna i ważna, dotycząca mocy obowiązującej powszechnego (w założeniu) Zwodu Praw z 1833 r. w relacji do praw prowincjonalnych. W Rosji pod tym względem wyróżniano pięć dużych obszarów terytorialnych, tj. Rosję właściwą, prowincje bałtyckie, kraj zachodni, Królestwo Polskie i Wielkie Księstwo Finlandzkie. Zamierzył This cały cykl artykułów, a pierwszy poświęcił prowincjom zachodnim. Wynikało to z ukończenia ostatecznie w latach 1837-1838 projektu tzw. Zwodu Zachodniego (Swod miestnych zakonow zapadnych gubernii), przygotowanego siłami polskich prawników w Petersburgu - Ignacego Daniłowicza i Franciszka Malewskiego ${ }^{7}$. Przepisy lokalnego Zwodu Zachodniego miały obejmować, według stosowanej wówczas nomenklatury rosyjskiej, tzw. Kraj Zachodni Cesarstwa, tj. terytoria dawnej Rzeczypospolitej, czyli Małorosję (gubernie czernichowska i połtawska), ziemie białoruskie (gubernie witebska i mohylewska) i porozbiorowe, zgrupowane w guberniach wileńskiej, grodzieńskiej, mińskiej, podolskiej, wołyńskiej, kijowskiej, łącznie z obwodem białostockim, oddanym Rosji w 1807 r. W swoich rozważaniach This przyjął założenie, iż opracowanie liczącego 2070 paragrafów Zwodu było efektem zapewnień władz rosyjskich dotyczących zachowania na terenach zabieranych Polsce praw miejscowych, choć głównie w obrębie prawa cywilnego, ustroju sądów i norm procesowych. Skonstatował, iż w sferze prawa publicznego (także w prawie karnym) nastąpiła już unifikacja z przepisami Cesarstwa, gdyż nie można nie uwzględniać interesów i działań „zwycięskiego Cesarstwa”".

5 Szerzej: ibidem, s. 133-168.

6 « Revue Étrangére et Française » 1838, Vol. V, s. 1-22. Był to jedyny jego tekst ujawniający autora w podtytule: Par M. This, maitre des requêtes á Saint-Pétersbourg.

$\mathrm{Z}$ planowanych This zdołał napisać tylko ten jeden artykuł. O kwestiach kodyfikacji w Rosji praw prowincjonalnych por. szerzej: A. Korobowicz, W. Witkowski, Prawo i sądy na zabranych wschodnich ziemiach Rzeczypospolitej w XIX wieku, „Czasopismo Prawno-Historyczne” 2003, nr 1, s. 61-84. Zob. także: W. Sobociński, Rozwój ustawodawstwa cywilnego w Królestwie Polskim $i$ w Rosji do rosyjskiej reformy sądowej (zarys historyczno-porównawczy), „Annales UMCS sectio G (Ius)" 1965, t. 12, s. 139 i n.; S. Godek, III Statut Litewski w dobie porozbiorowej, Warszawa 2012, s. $252 \mathrm{i} \mathrm{n.}$

8 A. This, op. cit., s. 8. 
II.

W tym kontekście This podjął się opisu ustawodawstwa polskiego od jego początków do XVIII stulecia. Choć blisko dwie trzecie jego tekstu dotyczyło rosyjskich poczynań nad zmianami w prawie omawianego obszaru oraz problematyki opracowania Zwodu Zachodniego, to poświęcenie dość znacznej części uwag prawu Rzeczypospolitej było znamienne - charakterystyczne metodycznie, gdyż ukazywało zasadnie punkt wyjścia, jaki zastał zaborca rosyjski, a tym samym było niezbędne konstrukcyjnie dla przejrzystości wywodów. This dał czytelnikowi spojrzenie całościowe, a dodatkowo odbiorcy zachodnioeuropejskiemu przedstawił dawne polskie prawo, co należało wówczas w piśmiennictwie do rzadkości. Tym bardziej, że czynił to dobry prawnik, mający znajomość historii, potrafiący pisać jasno i syntetycznie. Zanim przejdziemy do szczegółowego przedstawienia wywodów Thisa, należy wskazać na źródła jego opracowania. Niewątpliwie podstawowy materiał stanowiły prace i notatki z wykładów Jana Wincentego Bandtkiego (1783-1846) z historii prawa polskiego oraz Wacława Aleksandra Maciejowskiego (1792-1883) z prawa rzymskiego9. Obydwaj byli profesorami Thisa na Uniwersytecie Warszawskim w czasie jego studiów (1818-1821), sam This zaś wówczas odznaczał się - zdaniem mu współczesnych - „mocną i kolosalną pamięcią", a także sporządzaniem dokładnych notatek $\mathrm{z}$ wykładów ${ }^{10}$. W postaci książkowej Historia prawa polskiego Bandtkiego ukazała się w 1850 r. jako Dzieło pogrobowe. Pisana była w oparciu o własne wykłady uniwersyteckie, którymi dysponowal w $1838 \mathrm{r}$. This w Petersburgu w formie osobistych zapisek, a być może też tekstów udostępnionych przez Bandtkiego z Warszawy. Zbieżność sformułowań Thisa z poglądami i tezami Bandtkiego pozostawała bowiem jednoznaczna i wyrazista ${ }^{11}$. Poza wiedzą zaczerpniętą od Bandtkiego solidnie wykształcony, śledzący literaturę naukową This sięgnął do autorów osiemnastowiecznych bądź mu współczesnych, jak wspomniany wyżej przedstawiciel szkoły historycznej W.A. Maciejowski czy J. Lelewel bądź B. Rakowiecki.

W uwagach wstępnych This podkreślił, iż tworzone w Imperium zbiory praw prowincjonalnych w formie, jak to określił, Statutów nie zawierały przepisów o charakterze wyjątków od powszechnego prawa Cesarstwa, mających źródła w ustawodawstwie Rosji i dopuszczających modyfikacje w zależności od uwarun-

9 Biogramy obydwu w opracowaniu Anny Rosner zostały opublikowane w: Profesorowie Wydziału Prawa i Administracji Uniwersytetu Warszawskiego 1808-2008, red. G. Bałtruszajtys, Warszawa 2008, s. 23-25, 36-38.

10 Por. K. Dunin, Romuald Hube (1803-1890). Studium biograficzno-bibliograficzne, Warszawa 1904, s. 11-12.

11 Korzystając z prywatnych materiałów, This ani w tekście, ani w przypisach nie przywołał Bandtkiego. Treść wykładów Bandtkiego znana była już w końcu drugiego dziesięciolecia XIX w. Por. J. Bardach, Historia państwa i prawa Polski, t. 1: Do połowy XV wieku, Warszawa 1964, s. 28. 
kowań lokalnych. Przeciwnie, pisał, że miano praw prowincjonalnych odnosiło się do dawnych miejscowych ustawodawstw, obowiązujących na terenach wcielanych do Rosji i otrzymujących w trakcie przyłączania gwarancje, iż prawa te będą respektowane i utrzymywane. Takie formalne deklaracje jego zdaniem składały władze Rosji w stosunku do nabytków dawnej Rzeczypospolitej ${ }^{12}$. Tak też, dodajmy, w istocie było, kiedy to szeregiem ukazów od czasów Katarzyny II do ostatniego nabytku w 1807 r. utrzymano w mocy system prawa sądowego polsko-litewskiego z III Statutem Litewskim z 1588 r. jako głównym źródłem na czele ${ }^{13}$. Stąd według Thisa zasada utrzymania praw prowincjonalnych w Kraju Zachodnim stanowiła podstawę do podjęcia prac kodyfikacyjnych idących w kierunku ich ścisłego zebrania wraz z koordynacją norm, czego efektem był przedmiotowy Zwód Zachodni. Ze zrozumieniem podkreślał trudności podjętego dzieła przez kodyfikatorów, wynikające ze złożoności i skomplikowania systemu ustawodawstwa Rzeczypospolitej szlacheckiej.

Chcąc unaocznić odbiorcom europejskim skalę problemów, This w początkach rozważań zdecydował się na przedstawienie różnorodności praw polskich oraz braku jednolitego ustawodawstwa, co było konsekwencją organizacji politycznej i struktur społecznych dawnej Rzeczypospolitej. Podniósł, iż na obszarze Polski politycznie należy odróżniać Koronę od Litwy, a ich związek ustrojowo-prawny nie przyniósł państwa jednolitego, ale też przekraczał reguły federacji ${ }^{14}$. Z kolei, jak pisał, podział stanowy na szlachtę, duchowieństwo i mieszczaństwo pociągał za sobą odmienność praw tak publicznych, jak i sądowych. Ciekawe, iż ani Wincenty Skrzetuski, ani J.W. Bandtkie nie wyróżniali duchowieństwa jako oddzielnego stanu, a według tego ostatniego podział stanowy dotyczył szlachty i plebejuszy (tj. razem mieszczan oraz chłopów) ${ }^{15}$. Bandtkie podkreślał, iż chłopi w Rzeczypospolitej zostali pozbawieni wszelkich praw, dlatego This nie uznawał ich za stan społeczny. Natomiast w najnowszej historiografii ustroju i prawa polskiego wybitny znawca epoki Wacław Uruszczak wyraźnie wskazuje na następujące stany społeczne w dawnej Polsce: szlachtę, duchowieństwo, mieszczaństwo oraz chłopów ${ }^{16}$.

12 A. This, op. cit., s. 4.

13 Przepisy prawa karnego obowiązywały na terenach zabranych przez Katarzynę II do 1821 r., a w dziedzinie prawa cywilnego na ziemiach zaboru I do 1831 r., natomiast na pozostałych - do $1840 \mathrm{r}$. W czasie powstawania tekstu Thisa problem obowiązywania praw prowincjonalnych był więc jeszcze aktualny. Por. A. Korobowicz, W. Witkowski, op. cit., s. 67-71.

14 A. This, op. cit., s. 5. Dzisiaj autor najnowszej monografii Andrzej B. Zakrzewski wskazuje, iż Wielkie Księstwo Litewskie było we wspólnej Rzeczypospolitej prawnie jednym z dwóch jej członów, a praktycznie „stawało się jedną z jej trzech prowincji”. Por. A.B. Zakrzewski, Wielkie Księstwo Litewskie (XVI-XVIII). Prawo - ustrój-społeczeństwo, Warszawa 2013, s. 281.

15 Por. W. Organiściak, Wincentego Skrzetuskiego „Prawo polityczne narodu polskiego”, Katowice 2016, s. 248; J.W. Bandtkie, Historia prawa polskiego, Warszawa 1850, s. 269 i n., 533-566.

16 W. Uruszczak, Historia państwa i prawa polskiego, t. 1: 966-1795, Warszawa 2013, s. 191. 
W związku z powyższymi cechami zasadniczymi przeszłego ustroju Polski ukształtował się również system prawny, który według Thisa wyróżniał prawo powszechne (lois generales), prawo szczególne (lois particulières) oraz prawo pomocnicze (lois auxiliaires). Podział ten w uproszczony sposób szedł za konstrukcją przyjętą przez Bandtkiego. Mianowicie w odniesieniu do czasów dynastii Jagiellonów stał on na stanowisku trójdzielnego podziału prawa, rozróżniając prawa krajowe własne (inaczej ogólne), koronne i prowincjonalne, dotyczące stanu szlacheckiego i duchowieństwa, następnie prawa krajowe, przysposobione i osadnicze, obejmujące prawo miejskie i ormiańskie, oraz jako trzeci element prawo obce, pomocnicze, tj. prawo rzymskie, kanoniczne i lenne ${ }^{17}$. Pisząc o latach monarchii elekcyjnej, podział ten utrzymał, dodając tylko do pojęcia praw krajowych własnych prowincjonalne prawo litewskie, skodyfikowane w III Statucie z 1588 r. ${ }^{18}$

Modyfikacja dokonana przez Thisa polegała na uznaniu za prawo powszechne na terenie Korony prawa tworzonego przez ustawodawstwo królewskie i sejmowe w odniesieniu do zagadnień ogólnopaństwowych i stanu szlacheckiego oraz kodyfikację litewską. Efekty działalności polskich monarchów określał statutami i wskazywał na ich przykłady, począwszy od Kazimierza Wielkiego, kończąc na panowaniu Zygmunta Starego. Wysoko je stawiał, twierdząc, iż dały one podwaliny pod założenia ustrojowo-prawne oraz społeczne państwa. W odróżnieniu od nich, pisząc o konstytucjach sejmowych, oceniał je generalnie krytycznie, zwłaszcza z doby monarchów elekcyjnych. Podnosił, iż ustawodawstwo tego okresu wynikało często z potrzeb doraźnych, nie było usystematyzowane i petryfikowało wady ustroju politycznego ${ }^{19}$, choć $\mathrm{z}$ drugiej strony wyrażało dążność do powstawania jednolitego prawa polsko-litewskiego, co należy oceniać pozytywnie. Osobny akapit This poświęcił rezolucjom osiemnastowiecznej Rady Nieustającej, dzięki którym następowała interpretacja funkcjonującego prawa. Celnie przy tym zauważył, iż moc obowiązująca rezolucji bardziej wypływała z potrzeby zaradzenia niedostateczności ustawodawstwa i jego częstej nieużyteczności niż $\mathrm{z}$ rzeczywistego aktu suwerennej władzy ${ }^{20}$.

17 J.W. Bandtkie, op. cit., s. 472-473.

18 Ibidem, s. 694-717. O złożoności i niejednolitości pojęcia „prawo pospolite” (ius commune) pisał celnie w XX w. Konstanty Grzybowski. Zwrócił on uwagę na identyfikowanie prawa powszechnego z prawem ,całego państwa i całej ludności w przeciwstawieniu do praw partykularnych i stanowych", będącego narzędziem unifikacji prawa. Por. szerzej: K. Grzybowski, Teoria reprezentacji w Polsce epoki Odrodzenia, Warszawa 1959, s. 245-272.

19 Tu też wprost nawiązywał do poglądu Bandtkiego, negatywnie patrzącego na ustawodawstwo sejmowe. Por. J.W. Bandtkie, op. cit., s. 473, 695.

20 Rada Nieustająca znajdowała się bowiem pod silnym politycznym wpływem czynników rosyjskich. Por. Z. Kaczmarczyk, B. Leśnodorski, Historia państwa i prawa Polski, t. 2: Od połowy $X V$ wieku do r. 1795, Warszawa 1966, s. 475. O charakterze rezolucji Rady por. M. Głuszak, Zbiór rezolucji interpretacyjnych Rady Nieustającej z lat 1786-1788, Łódź 2014, s. 18-23. 
Konsekwencją odmiennego podejścia do obszaru prawa powszechnego było ujęcie przez Thisa praw szczególnych. Połączył on w tym pojęciu prawa prowincjonalne (używał też terminu „lokalne”), poza statutem litewskim, z prawem kanonicznym oraz niemieckim dla miast. Z praw prowincjonalnych jego zdaniem istotną wagę dla polskiego systemu prawnego zachowywały następujące:

- zwyczaje ziemi krakowskiej (Consuetudines terrae Cracoviensis) z szesnastowiecznego zbioru Jana Łaskiego. This zaznaczył, iż korzenie szeregu norm prawnych tkwiły w tymże spisie prawa ${ }^{21}$,

- kodyfikacje na Mazowszu, a szczególnie tzw. Ekscepta mazowieckie, utrzymujące moc od 1577 r. do końca szlacheckiej Rzeczypospolitej. Tu This ze znajomością rzeczy podkreślił, iż tak ważna w prawie instytucja intromisji, czyli wprowadzenia w posiadanie (jako koniecznego elementu przy przenoszeniu własności), miała najlepszą regulację w prawie mazowieckim i w praktyce funkcjonowała na obszarze Korony ${ }^{22}$,

- Prawo Prus Królewskich w postaci Korektury Prawa Pruskiego (Ius terrestre nobilitatis Prussiae), zatwierdzonej przez sejm w 1598 r. Tu również This wskazał na jej ogólnopaństwowe znaczenie i stosowanie w Koronie, szczególnie w zakresie prawa spadkowego ${ }^{23}$.

Jeśli chodzi o prawo kanoniczne Kościoła rzymsko-katolickiego, to This, opierając się na zdaniu Bandtkiego, uznawał je za prawo dla duchowieństwa, ale zarazem podkreślał jego moc obowiązującą i znaczenie dla ludzi świeckich w dziedzinach podlegających Kościołowi ${ }^{24}$. Konstatował, iż system ten należy stawiać na równi z prawem krajowym, choć nie przeprowadził jego podziału na normy prawa powszechnego i miejscowego, tak jak to uczynił Bandtkie ${ }^{25}$. Obszerny akapit This poświęcił problematyce miast królewskich i prawa miejskiego. Wskazał na duże znaczenie procesów lokacyjnych miast na prawie niemieckim (zwłaszcza magdeburskim), ukształtowanie się samorządności miejskiej oraz rolę polityczną, jaką miasta polskie odgrywały jeszcze za czasów Jagiellonów. Podkreślił ukształtowanie się od XIV w. polskiego najwyższego sądownictwa miejskiego w postaci sądu wyższego prawa niemieckiego na zamku krakowskim i odwoławczego komisarskiego sądu królewskiego (tzw. sądu sześciu miast ${ }^{26}$. $\mathrm{Z}$ drugiej strony, też za Bandtkiem, choć w ostrzejszych sformułowaniach, podnosił antymiejską politykę szlachty i związane z nią ustawo-

21 Por. Z. Kaczmarczyk, B. Leśnodorski, op. cit., s. 19.

22 A. This, op. cit., s. 8. Por. W. Dutkiewicz, Prawa cywilne, jakie w Polsce od roku 1347 do wprowadzenia Kodeksu Napoleona obowiazywaty, Warszawa 1869, s. 140-141.

23 A. This, op. cit., s. 8.

24 Por. J.W. Bandtkie, op. cit., s. 715-716.

25 Ibidem, s. 487-488, 499 i n.

26 Por. J. Bardach, op. cit., s. 484-485. 
dawstwo. Pisał, iż w dobie Polski elekcyjnej następował szybki upadek miast, zanikały handel i rzemiosło, a ludność miejska zubożała tak, że „po upływie niecałych dwóch stuleci jedynie stosy ruin znakowały miejsca, gdzie niegdyś wznosiły się liczne bogate miasta" 27 . W ogóle nie wspomniał o dokonywanych w XVIII stuleciu próbach poprawy położenia miast w postaci m.in. powoływanych Komisji Boni Ordinis, przeciwnie - zaznaczał, iż konstytucją sejmową z 1776 r. pozbawiono autonomicznych praw 150 samorządów miejskich, podporządkowując je władzy starostw. Było to sformułowanie dość nieprecyzyjne, a nawet demagogiczne, gdyż w istocie powyższa ustawa sejmowa dotyczyła tylko Wielkiego Księstwa Litewskiego i małych miasteczek o charakterze agrarnym, gdzie przywileje wynikające $\mathrm{z}$ dawnego prawa magdeburskiego ani nie były stosowane, ani nie przynosiły korzyści mieszkańcom ${ }^{28}$. Wiązała się ona też ściśle z reformatorską działalnością od 1765 r. litewskiej Komisji Skarbu w obszarach skarbowości, gospodarki i handlu ${ }^{29}$. Ustawodawstwo miejskie Sejmu Wielkiego skwitował This jednym zdaniem - zasługiwało ono według niego na pozytywną ocenę, ale ze względu na zbyt krótki czas obowiązywania reformy nie zostało urzeczywistnione ${ }^{30}$.

Do praw pomocniczych zaliczał This system prawa lennego (feudalnego) oraz prawo rzymskie. Wyjaśnił, iż obydwie kategorie praw miały służyć wypełnieniu luk w prawie krajowym i od razu dodał, iż kwestia ich używania w Polsce miała charakter kontrowersyjny, szczególnie w odniesieniu do prawa rzymskiego. Prawo lenne i system zależności lennej według niego nie odgrywały prawie żadnej roli w dziejach polskiego prawa, zanikły zwłaszcza w Koronie wraz z końcem dynastii Piastów ${ }^{31}$. Natomiast co do stosowania prawa rzymskiego i traktowania go jako źródła prawa uchylił się od głębszego wywodu - napisał tylko, iż zawsze stało ono w Polsce na ,piedestale nauki”, ale jego praktyczna użyteczność była żadna, choć - jak zaznaczył - byli zwolennicy poglądów odmiennych ${ }^{32}$. W zakończeniu tej części wywodów dodał jeszcze, jako pewną osobliwość, wprowadzenie przez polski sejm w 1775 r. do ustawy o prawie wekslowym dzieła naukowe-

27 A. This, op. cit., s. 9. Bandtkie również pisał, iż „czyniono w prawodawstwie ziemiańskim rozmaite zmiany i ścieśnienia w prawach osadniczych niemieckich, mając na uwadze korzyść $\mathrm{i}$ interes swój własny, to jest szlachectwo i szlachtę". Por. J. Bardach, op. cit., s. 496.

28 Volumina Legum, t. 8, Petersburg 1860, s. 567-568. Przepisy te nie obejmowały miast większych, takich jak Wilno, Kowno, Lida, Troki, Nowogródek, Mińsk, Pińsk, Wołkowysk, Mozyrz, Brześć czy Grodno.

29 Por. G. Bałtruszajtys, Sadownictwo Komisji Skarbowych w sprawach handlowych i przemystowych (1764-1794), Warszawa 1977, s. 71 i n.

30 A. This, op. cit., s. 9-10.

31 Ibidem, s. 10. Nieco później, na Litwie, This powielał pogląd Bandtkiego. Por. J.W. Bandtkie, op. cit., s. 716.

32 Być może nie chciał otwarcie występować przeciwko swemu profesorowi, gdyż Bandtkie głosił tezę o funkcjonowaniu prawa rzymskiego w sądach miejskich. Por. ibidem, s. 714-715. 
go Jana Gottlieba Heineciusa pt. Elementa iuris cambialis ${ }^{33}$. Miało ono być in subsidium do wprowadzanych przepisów i stosowane w sądach. Jak przytomnie i złośliwie zauważył This, stanowiło „być może pierwszy przykład traktatu dydaktycznego, który wyniesiono w ustawodawstwie do takiej godności" ${ }^{34}$.

Po przedstawieniu stanu ustawodawstwa w drugiej części wywodów This zajął się problemem kodyfikacji prawa polskiego. Złożoność obowiązujących w dawnej Polsce przepisów wskazywała na skalę trudności w opracowywaniu jednolitości prawa, a nawet $\mathrm{w}$ jego uporządkowaniu i wprowadzeniu przejrzystości, tak potrzebnych w praktyce sądowej. Do zagadnień natury kodyfikacyjnej dochodziła słabość aparatu wykonawczego państwa. Zdaniem Thisa brak w sferze zarządu państwem silnego centrum, mającego wolę polityczną, widzącego w prawie element jedności państwa oraz wyposażonego w możliwości sprawcze, zaważył na braku kodyfikacji prawa w Polsce. Był w tej ocenie zdecydowanie krytyczny - podkreślił wewnętrzne konflikty i spory (rozdzierające system państwa szczególnie w czasach bezkrólewia), egoistyczną postawę szlachty i duchowieństwa, słabość prac sejmowych. Posunął się nawet do stwierdzenia, iż społeczeństwo szlacheckie opanowało paradoksalne i zgubne przekonanie, iż bałagan ustawodawczy jest najlepszym i pożądanym stanem ${ }^{35}$. Jedynie Wielkie Księstwo Litewskie miało swój statut z 1588 r. i ten stan uporządkowanego prawa zasługiwał na pozytywną ocenę. Rozproszone ustawodawstwo, funkcjonujące w ciągu stuleci istnienia państwa, było jego zdecydowaną ułomnością i poważnym błędem, niemniej nie oznaczało niepodejmowania prób zmiany tego stanu rzeczy. This skrzętnie odnotował zarówno podejmowane prace kodyfikacyjne, jak i inicjatywy prywatne prowadzące do sporządzenia zbiorów praw. Szczególnie wysoko ocenił prace kodyfikacyjne za panowania Zygmunta Starego, idące od 1519 r., których efektem była Korektura Praw z 1532 r. ,podziwiana jeszcze w jego czasach z uwagi na zalety co do metody i sposobu redagowania"36. Podkreślił ponadto, iż merytoryczne prace różnych komisji powoływanych od XVI do XVIII stulecia, stawiających sobie za cel ułożenie, skoordynowanie bądź zreorganizowanie obowiązującego prawa, zasługiwały na uznanie i pozostały pomnikiem ,żarliwych" wysiłków, niestety bezowocnych ze względu na ,uporczywy opór ciała ustawodawczego"37. W efekcie braku kodyfikacji podstawowym źródłem prawa stawały

33 Volumina ..., s. 123. Praca ta ukazała się w 1742 r. w Amsterdamie i miała osiem wydań. Por. R. Jastrzębski, Prawo wekslowe w dawnej Rzeczypospolitej, „Czasopismo Prawno-Historyczne" 2003, nr 1, s. 51-52.

${ }^{34}$ A. This, op. cit., s. 10. Bandtkie (op. cit., s. 717) ocenił ten fakt jako dowód „niewiadomości i obojętności ówczesnych prawodawców i braku nauki”.

35 A. This, op. cit., s. 12.

36 Ibidem. Por. dzisiejszą ocenę dokonaną przez W. Uruszczaka w monografii Próba kodyfikacji prawa polskiego w pierwszej połowie XVI wieku (Warszawa 1979).

37 A. This, op. cit., s. 11-12. 
się zbiory ustawodawstwa, zresztą o różnorodnym charakterze. Na czoło wysunęły się tu Volumina Legum (obejmujące lata 1347-1780) jako - zdaniem Thisa - zbiór najbardziej kompletny. Następnie, nie wskazując tytułów, dodatnio ocenił zbiory praw sporządzone w czasach Jagiellonów (można się domyślać, iż chodziło mu m.in. o zbiór Jana Łaskiego i prace Jakuba Przyłuskiego, Jana Herburta czy Mikołaja Jaskiera), a także Stefana Batorego i Władysława IV Wazy (choćby Jana Januszowskiego czy Pawła Szczerbica i Stanisława Łochowskiego). Odnotował jeszcze jako istotne dla stosowania prawa sporządzane repertoria ustawodawstwa i liczne Promptuaria. Mimo braku mocy obowiązującej, a pisanych, tak jak pierwsze, metodą alfabetyczną, drugie zaś w formie podręczników, cieszyły się popularnością oraz praktycznym zastosowaniem ${ }^{38}$.

Końcowy fragment rozważań This poświęcił Zbiorowi Praw Sądowych Andrzeja Zamoyskiego z lat 1776-1780. Słusznie zauważy1, iż jego twórcy stanęli na stanowisku pogodzenia idei zbioru prawa obowiązującego z potrzebami działań reformatorskich zarówno w dziedzinie prawa sądowego, jak i w kwestiach ustroju społecznego i politycznego. Podkreślił, iż punktem wyjścia dla prac kodyfikacyjnych było dawne prawo polskie, ale twórcy Zbioru mogli sięgać również do praw prowincjonalnych, jak Statut Litewski czy prawo mazowieckie, do prawa miejskiego oraz praw obcych, z prawem rzymskim na czele. Kodyfikatorzy mieli poza tym uwzględniać założenia osiemnastowiecznej myśli oświeceniowej w obszarze tworzenia prawa, takie jak: zupełność, jasność czy zwięzłość kodeksu. Tak sformułowane myśli Thisa dowodzą, iż znał on sporządzone w 1776 r. tzw. Reguly fundamentalne do stanowienia prawa, które były, jak pisał, „planem i wskazówką" dla redagujących nowe prawo ${ }^{39}$. Niewątpliwie posiadał dobrą znajomość tak samego projektu Zbioru, jak i literatury polityczno-prawnej polskiego Oświecenia. Zbiór Zamoyskiego uznawał za dojrzały, a kanclerza określał jako odważnego nowatora. Omawiając powody odrzucenia Zbioru przez sejm w 1780 r., pozostawił jednak przekaz zbyt ogólnikowy i zdecydowanie nieprecyzyjny. Generalnie - tak zresztą, jak uważano w opinii publicznej pierwszej połowy XIX w. - uznawał za głównych opozycjonistów Zbioru sfery kościelne oraz konserwatywną szlachtę. Zupełnie pominął za to, pisząc przecież w Petersburgu, działania zewnętrzne, zwłaszcza rosyjskie ${ }^{40}$. Natomiast jako bezpośrednie powody odrzucenia Zbioru wymienił sformułowane w nim propozycje likwidacji nuncjatury apostolskiej w Polsce, wprowadzenie zakazu kontaktów ze Stolicą Apostolską i wymóg poddania aktów papieskich

38 Ibidem, s. 12-13.

39 Ibidem, s. 19. Por. omówienie Regut w: E. Borkowska-Bagieńska, Zbiór Praw Sądowych Andrzeja Zamoyskiego, Poznań 1986, s. 67-68. Zdaniem autorki twórcą Reguł był najprawdopodobniej sam Zamoyski.

40 Por. dzisiejszą ocenę powodów odrzucenia Zbioru wyrażoną przez E. Borkowską-Bagieńską (ibidem, s. 317-323). 
akceptacji sejmowej. Z kolei dla szlachty jego zdaniem nie do przyjęcia była l'émancipation des serfs (choć nie tłumaczył, czy chodziło mu o wolność i równouprawnienie, czy tylko o likwidację pańszczyzny), jak również możność dopuszczenia mieszczan do sprawowania niektórych urzędów w sądownictwie i administracji. Tak radykalnych i jednoznacznych postanowień Zbiór nie przewidywał, a This posłużył się tu poglądami głoszonymi przez Hugona Kołłątaja w Listach Anonima ${ }^{41}$. Zapewne uczynił to, by wzmocnić swój pogląd o negatywnej roli szlachty i Kościoła rzymsko-katolickiego w dawnej Rzeczypospolitej $^{42}$. Na koniec wywodów odnotował, iż Zamoyski otrzymał od sejmu w $1780 \mathrm{r}$. podziękowanie za swą pracę, ale jednocześnie zaznaczył podjętą uchwałę sejmową o zakazie wskrzeszania tego rodzaju projektów w przyszłości.

W ten sposób This zakończył uwagi nad dawnym polskim ustawodawstwem, by w drugim fragmencie Notice zająć się jego losami pod panowaniem rosyjskim oraz Zwodem Zachodnim. Ta część wykracza poza ramy niniejszych rozważań. Dodajmy tylko, iż Zwód Zachodni został przez władze rosyjskie odrzucony i od $1840 \mathrm{r}$. w guberniach zachodnich oraz obwodzie białostockim wprowadzono rosyjski Zwód Praw uchylający obowiązujące dotychczas prawa litewsko-polskie.

Oczywiście pytanie, na ile tekst Thisa przyczynił się do znajomości prawa polskiego wśród czytelników Europy Zachodniej, musi pozostać bez odpowiedzi. Niemniej ukazał się w dobrym czasopiśmie prawniczym, a sam autor cieszył się zasłużoną renomą. W swoich uwagach This uwzględnił stan wiedzy polskiej nauki prawa w pierwszej połowie XIX w., szczególnie uprawianej na Uniwersytecie Warszawskim do $1830 \mathrm{r}$. Ukazał też swoje poglądy w ocenie przeszłego prawa. Innymi słowy, spełnił należycie obowiązek człowieka nauki, a dodatkowo udostępnił wiedzę w tematyce rzadko poruszanej na gruncie obcym, pozostając $\mathrm{w}$ tej mierze $\mathrm{w}$ wąskim kręgu uczonych publikujących poza czasopiśmiennictwem krajowym. Tekst przedstawiający dawne prawo państwa ówcześnie już nieistniejącego miał niewątpliwie obok walorów poznawczych wydźwięk narodowy, uświadamiający europejskiemu środowisku prawniczemu problematykę polskiego ustawodawstwa. $\mathrm{Z}$ tego powodu, jak się wydaje, zasłużył na przypomnienie i współcześnie, tym bardziej że dokonywane przez niego oceny miały generalnie trafny charakter i mimo upływu lat lokują się właściwie w historiografii prawniczej.

${ }^{41}$ Por. Z. Kaczmarczyk, B. Leśnodorski, op. cit., s. 495-496, 515-517.

42 Warto tu wspomnieć, iż rodzina Thisa i on sam byli kalwinami. Por. W. Witkowski, op. cit., s. $27 \mathrm{in}$. 


\section{BIBLIOGRAFIA}

Bałtruszajtys G., Sadownictwo Komisji Skarbowych w sprawach handlowych i przemystowych (1764-1794), Warszawa 1977.

Bandtkie J.W., Historia prawa polskiego, Warszawa 1850.

Bardach J., Historia państwa i prawa Polski, t. 1: Do połowy XV wieku, Warszawa 1964.

Borkowska-Bagieńska E., Zbiór Praw Sądowych Andrzeja Zamoyskiego, Poznań 1986.

Dunin K., Romuald Hube (1803-1890). Studium biograficzno-bibliograficzne, Warszawa 1904.

Dutkiewicz W., Prawa cywilne, jakie w Polsce od roku 1347 do wprowadzenia Kodeksu Napoleona obowiazywały, Warszawa 1869.

Głuszak M., Zbiór rezolucji interpretacyjnych Rady Nieustającej z lat 1786-1788, Łódź 2014.

Godek S., III Statut Litewski w dobie porozbiorowej, Warszawa 2012.

Grzybowski K., Teoria reprezentacji w Polsce epoki Odrodzenia, Warszawa 1959.

Jastrzębski R., Prawo wekslowe w dawnej Rzeczypospolitej, „Czasopismo Prawno-Historyczne” 2003, $\mathrm{nr} 1$.

Kaczmarczyk Z., Leśnodorski B., Historia państwa i prawa Polski, t. 2: Od połowy XV wieku do r. 1795, Warszawa 1966.

Korobowicz A., Witkowski W., Prawo i sady na zabranych wschodnich ziemiach Rzeczypospolitej w XIX wieku, „Czasopismo Prawno-Historyczne” 2003, nr 1.

Organiściak W., Wincentego Skrzetuskiego „Prawo polityczne narodu polskiego”, Katowice 2016.

Rosner A., Jan Wincenty Bandtkie (1783-1846), [w:] Profesorowie Wydziału Prawa i Administracji Uniwersytetu Warszawskiego 1808-2008, red. G. Bałtruszajtys, Warszawa 2008.

Rosner A., Wacław Aleksander Maciejowski (1792-1883), [w:] Profesorowie Wydzialu Prawa i Administracji Uniwersytetu Warszawskiego 1808-2008, red. G. Bałtruszajtys, Warszawa 2008.

Sobociński W., Rozwój ustawodawstwa cywilnego w Królestwie Polskim i w Rosji do rosyjskiej reformy sądowej (zarys historyczno-porównawczy), „Annales UMCS sectio G (Ius)” 1965, t. 12.

This A., Notice sur la coordination des lois provinciales de l'Empire de Russie, " Revue Etrangére et Française » 1838, Vol. 5.

Uruszczak W., Historia państwa i prawa polskiego, t. 1: 966-1795, Warszawa 2013.

Uruszczak W., Próba kodyfikacji prawa polskiego w pierwszej połowie XVI wieku, Warszawa 1979. Volumina Legum, t. 8, Petersburg 1860.

Witkowski W., Aleksander This i Jan Kanty Wolowski - wybitni prawnicy Królestwa Polskiego, Lublin 2001.

Zakrzewski A.B., Wielkie Księstwo Litewskie (XVI-XVIII). Prawo-ustrój-społeczeństwo, Warszawa 2013.

\section{SUMMARY}

Aleksander This (1803-1864), an outstanding Polish lawyer, arrived in Petersburg after the outbreak of the November Uprising. There he got involved in scientific work and in 1838 he published his article entitled Notice sur la coordination des lois provincionales de L'Empire de Russie in a French juridical magazine "Reuve étrangère et française de legislation". The text presents the problem of codification of provincial laws on the Polish territories taken over by Russia during the annexations by the end of the $18^{\text {th }}$ century. It includes the description and the assessment of the legislation of the Polish law in the Commonwealth of Poland and Lithuania. The author elaborates not only on the systems of laws that were in force and their classifications but also on the attempts to codify the law between the $14^{\text {th }}$ and $18^{\text {th }}$ centuries. He gives a detailed description of ordinary law, particular laws and auxiliary laws that functioned in former Poland. This critically evaluated lack of the codification of law, especially the failure of the codification in 1532, the so-called Rectification 
of Laws and The Collection of Juridical Laws by Andrzej Zamoyski from the years between 1776 and 1780. The advantage of the publication is the introduction of the Western European readers to the problems of the former Polish law.

Keywords: Commonwealth of Poland and Lithuania; Polish law; codification of law

\section{STRESZCZENIE}

Aleksander This (1803-1864), wybitny polski prawnik czasów Królestwa Polskiego, po wybuchu powstania listopadowego znalazł się w Petersburgu. Tam zajmował się pracą naukową i w 1838 r. opublikował we francuskim czasopiśmie prawniczym „Revue etrangére et française de legislation" artykuł pt. Notice sur la coordination des lois provinciales de l'Empire de Russie. W tekście tym omówił problem kodyfikacji praw prowincjonalnych na zabranych przez Rosję ziemiach polskich podczas zaborów w końcu XVIII w. This zamieścił w nim opis i ocenę ustawodawstwa prawa polskiego w Rzeczypospolitej szlacheckiej. Omówił też systemy praw obowiązujących i ich klasyfikacje oraz próby kodyfikowania prawa od XIV do XVIII w. Ponadto szczegółowo przedstawił prawo powszechne, prawa szczególne oraz pomocnicze, jakie funkcjonowały w dawnej Polsce. Krytycznie ocenił brak skodyfikowania prawa, a zwłaszcza niedojście do skutku kodyfikacji z 1532 r. tzw. Korektury Praw i tzw. Zbioru Praw Sadowych Andrzeja Zamoyskiego $\mathrm{z}$ lat 1776-1780. Walorem jego publikacji było przedstawienie czytelnikom zachodnioeuropejskim problematyki dawnego prawa polskiego.

Słowa kluczowe: Rzeczpospolita szlachecka; prawo polskie; kodyfikacja prawa 